\title{
O TEXTO LITERÁRIO: ESPAÇOS DE RESISTÊNCIA
}

\author{
Sandra Zely Alves Silva Laranjeiras ${ }^{1}$ \\ Maria Helena da Rocha Besnosik ${ }^{2}$
}

\section{Introdução}

O texto literário é - pela complexidade inerente às literaturas de modo geral - um espaço aberto a diferentes diálogos nos quais poderemos reconhecer, ainda que em caráter de inferência, situações de resistência incorporadas às tramas e aos personagens. Surge, então, daí, o nosso objeto de análise: a categoria resistência nos espaços da literatura, a partir de dois textos: o Romance "Hibisco Roxo" de Chimamanda Ngozi Adichie e o Conto "Pai contra mãe" de Machado de Assis, analisada à luz da Teoria Crítica, principalmente as contribuições de Theodor Adorno, no tocante à arte. Propomos discutir o quanto o texto literário tem sido tomado tanto pelo autor, quanto pelo leitor como local de inferência e reflexão sobre a resistência às barbáries do mundo civilizado.

Este estudo é fruto das ações extensionistas desenvolvidas no Projeto de Extensão Leitura Itinerante: uma alternativa de formação de leitores, vinculado ao Núcleo de Leitura Multimeios da Universidade Estadual de Feira de Santana na Bahia. Esses ambientes de formação têm nos oportunizado refletir sobre o papel do texto literário no sentido estético e formativo. Assim, gerou-se em nós o interesse de desenvolver este trabalho que buscamos inscrever na possibilidade de se tomar a obra de arte como espaço de resistência, mais especificamente, o texto literário. O que pode a literatura? Que poder esta evoca com forças de nos deslocar para outros mundos e, ao mesmo tempo, de nos devolver para o nosso com percepções mais aguçadas?

Refletindo sobre tais questões, tomamos como referência a Teoria Crítica da sociedade a fim de análise dos textos abordados, partindo do contraponto de muitos ditos, de diferentes pontos de vista, numa tentativa de dizer que é possível sim, por meio da arte, questionar a nossa própria realidade. É possível falarmos de um passado que ainda se faz presente, é possível falarmos de homens e mulheres com suas especificidades, é possível falarmos de outros mundos, de outras vidas, é possível incomodar o leitor e assim, tirá-lo da zona de conforto e enveredá-lo por outros universos mais amplos e abertos a possíveis transformações.

Como já sinalizado nos debruçaremos sobre dois textos ficcionais: um Conto de Machado de Assis "Pai contra mãe" publicado no século XIX e o Romance de Chimamanda Ngozi Adichie "Hibisco Roxo" publicado no século XXI. Estas obras não serão tomadas como objetos de comparação. O que elas nos atêm como relevância são as singularidades que cada uma traz inscritas em um tempo, lugar, costumes, valores que certamente conduzem o leitor a pensar no cotidiano dos personagens, na inserção desses sujeitos em uma determinada realidade carregada de contradições que fazem parte das sociedades modernas. E aí perguntamos: como essas obras se inserem enquanto espaços de resistência? Por que pensar a literatura no viés desses espaços?

\section{A Teoria Crítica e a literatura como espaço de resistência}

A arte como forma de resistência é referendada por Adorno (2001) em “A arte é alegre?", quando ele lança suspeitas sobre o que há de verdadeiro na "alegria" da arte e, se há alegria,

\footnotetext{
${ }^{1}$ Professora da Educação Básica e mestranda do Programa de Pós-graduação em Educação - PPGE - Universidade Estadual de Feira de Santana - UEFS.

${ }^{2}$ Professora Titular do Departamento de Educação da Universidade Estadual de Feira de Santana - UEFS.
} 
como poderia ser interpretada enquanto resistência a um mundo flagelado por barbáries impostas pelo mundo objetivo. Se a autenticidade da alegria da arte morre em contextos de barbáries, se lhe inibe a criação, o que pode a obra de arte e mais especificamente o texto literário, nos colocando diante de realidades a serem pensadas e analisadas?

Reportando-se à resistência da arte, Adorno suscita também a possibilidade, mesmo que trivial, da alegria que a caracteriza na sua essência, não aos conteúdos, abordagens, mas àquilo que se opõe, pois estes ao serem administrados, não propõem liberdade criativa mediante a "mera existência que contradiz e a que opõe resistência" (p. 12).

Importa ressaltar que Adorno (2000) nos alerta que o processo de emancipação dos sujeitos se dá pela resistência e pela autonomia. O texto literário pode se constituir esse espaço, uma vez que ao adentramos na linguagem ficcional que emerge de uma dada realidade, nós, leitores, temos a oportunidade de conhecer lugares, pessoas, vidas, conflitos, costumes que fazem um contraponto às nossas próprias vidas.

A Teoria Crítica possibilita à contemporaneidade a visão de estética enquanto campo privilegiado de conhecimento acerca da experiência subjetiva humana, pensando desta forma, também, a literatura. Para a Teoria Crítica, cujo objetivo é tomar a realidade e analisá-la, dialeticamente, com vistas a superações de forças que se oponham à emancipação e à liberdade, a obra literária é capaz de produzir efeitos de análise acerca das manifestações sociais e suas movimentações subjetivas, por isso mesmo, de resistência.

\section{"Pai contra mãe" e as possíveis formas de resistência}

Machado de Assis nos apresenta em "Pai contra Mãe" uma sociedade escravocrata, marcada por violência e opressão, retratando, também, o opressor, o oprimido, a escravidão, o poder. Opta por iniciar o seu texto descrevendo os instrumentos de tortura utilizados no período da escravidão e o ofício de capitão do mato.

A escravidão levou consigo ofícios e aparelhos, como terá sucedido a outras instituições sociais. Não cito alguns aparelhos senão por se ligarem a certo ofício. Um deles era o ferro ao pescoço, outro o ferro ao pé; havia também a máscara de folha-de-flandres. A máscara fazia perder o vício da embriaguez aos escravos, por lhes tapar a boca. Tinha só três buracos, dous para ver, um para respirar, e era fechada atrás da cabeça por um cadeado (p. 303).

Percebemos uma tentativa de situar o leitor sobre o que vai tratar a sua narrativa. Depois, passa a relatar a história de Candinho que se torna um capitão do mato em função da necessidade de sobreviver conforme situações dadas aos menos favorecidos no Brasil de então, sem condições de conseguir um outro emprego:

Cândido Neves, - em família, Candinho, - é a pessoa a quem se liga a história de uma fuga, cedeu à pobreza, quando adquiriu o ofício de pegar escravos fugidos. Tinha um defeito grave esse homem, não aguentava emprego nem ofício, carecia de estabilidade (...) (p. 304).

Candinho se casa e vai morar com a esposa na casa da tia dela. Passado pouco tempo a sua mulher fica grávida. Quando a criança nasce, eles com muita dificuldade percebem a impossibilidade de criar o filho em função da pobreza. Candinho, estimulado pela tia, pensa em deixar o filho na roda dos enjeitados, entretanto no caminho vê a escrava que está sendo procurada. Ali, ele enxerga a possibilidade de conseguir algum dinheiro e adiar a entrega do 
filho para a adoção. A escrava está esperando um filho, porém Candinho se investe de algoz e consegue pegá-la; ela se rebela, grita, pede compaixão. Candinho, entretanto, está surdo ao seu lamento, à sua luta e entrega-a ao patrão. Na luta, Arminda aborta o filho e Candinho retorna para casa com a consciência de que fez o melhor para a sua família.

No desenvolver da trama podemos perceber que a resistência às condições sociais vai sendo percebida, conforme apresentação das personagens. Abaixo, as analisaremos de acordo com a perspectiva de Adorno (2000) de resistência como ação/reação à dominação, à castração da liberdade e da autonomia:

- As personagens Cândido, Clara, Mônica, tia de Clara, o dono da farmácia, apresentam resistência negativa, quando aceitam o que lhes é imposto sem contestação ou reação, sem consciência das injustiças sociais;

- O dono da escrava apresenta resistência nula, pois simboliza os interesses dos que detêm o poder, a dominação;

- Já Arminda, a escrava, apresenta resistência positiva, pois reage à sua condição de escravizada, fugindo e brigando pelo seu direito de ser livre, de ser mãe:

Arminda voltou-se sem cuidar malícia. Foi só quando ele, tendo tirado o pedaço de corda da algibeira, pegou dos braços da escrava, que ela compreendeu e quis fugir. Era já impossível. Cândido Neves, com as mãos robustas, atava-lhe os pulsos e dizia que andasse. A escrava quis gritar, parece que chegou a soltar alguma voz mais alta que de costume, mas entendeu logo que ninguém viria libertá-la, ao contrário. Pediu então que a soltasse pelo amor de Deus. (p. 312)

Este conto de Machado nos coloca em um lugar e em um tempo que não passou. Ele, ao trazer o tema da escravidão, visto sob várias óticas pelos personagens, deixa para o leitor o espaço da reflexão em um contexto muito adverso e cheio de dificuldades. Que personagem é Candinho que também é pobre, oprimido, mas se reveste de opressor para poder ter um reconhecimento da sua família? O autor coloca o leitor diante de um dilema, como o título do próprio texto diz "Pai contra mãe". A leitura desse conto na atualidade convoca o leitor a situarse num tempo e num contexto, ora distante, mas vívido. E nos perguntamos: O que pode a literatura frente a essa realidade?

\section{Hibisco Roxo: Como resistir às ações do colonialismo?}

No livro de Chimamanda "Hibisco Roxo" nos deparamos com uma detalhada apresentação de um país Africano, a Nigéria, sob a colonização branca, nos mostrando a violência, a opressão, o fanatismo religioso, o preconceito e a resistência.

A história gira em torno de uma família financeiramente bem sucedida, um pai empresário, extremamente religioso ligado ao catolicismo, que rejeita a religião da sua família, as tradições do seu povo. A aculturação religiosa e o que surge daí é quase sempre o centro dos conflitos:

As coisas começaram a se deteriorar lá em casa quando meu irmão, Jajá, não recebeu a comunhão, e Papa atirou seu pesado missal em cima dele e quebrou as estatuetas da estante. Havíamos acabado de voltar da igreja. Mama colocou as palmas molhadas de água benta sobre a mesa de jantar e foi para o segundo andar da casa trocar de roupa. Mais tarde ela amarraria as palmas na forma de cruzes e penduraria na parede ao lado da foto com moldura dourada da nossa família. (p. 6) 
Kamili é a personagem central que vai narrar-se a partir de conflitos familiares, políticos, sociais. O pai, dono de um jornal que questiona o sistema vigente, mas ao mesmo tempo um homem extremamente conservador; uma mãe que aceita, aparentemente, todas as regras impostas por uma sociedade machista e conservadora; dois filhos, um menino e uma menina, que sofrem na tentativa de compreender-se e à sua história frente a tantos conflitos:

[...] nosso entregador trazia quatro edições de cada um dos principais jornais todas as manhãs, por ordem de Papa. Lemos o Standard primeiro. Só ele publicara um editorial crítico, pedindo que o novo governo militar rapidamente implementasse um plano de retorno à democracia. Papa leu um dos artigos no Nigéria Today em voz alta. Era uma coluna escrita por um homem que insistia que chegara mesmo a vez do presidente militar, já que os políticos haviam perdido o controle e nossa economia estava uma bagunça. (p. 31)

Não gosto de mandar vocês na casa de um pagão, mas Deus vai protege-los disse Papa. Papa foi para a sala de estar. Ouvi mais vozes, mais gente entrando para dizer "Nnu nu" e reclamar de como a vida era dura, de como não podiam nem comprar roupas novas para seus filhos naquele Natal. (p. 69)

O final do romance surpreende o leitor, ao buscar a ruptura com este modelo conservador de sociedade moldado tão ao gosto do colonizador branco.

Analisando a questão da resistência em Hibisco Roxo podemos perceber:

- A resistência positiva: Kambili, Jajá, Mãe, Tia, quando se opõem às opressões advindas da relação com o pai autoritário e buscam caminhos alternativos para suas vidas.

- Resistência negativa: Pai, quando se coloca a serviço da religião do colonizador, negando suas tradições.

- Resistência nula: Capitalistas, tanto os nativos quanto os representantes do colonizador;

- Resistências atravessadas, as contradições, pois as tensões dão espaços para superação.

Chimamanda nos transporta para uma Nigéria nos dias de hoje, moderna, com traços de uma colonização que se impõe mudando valores, costumes, enfim, a cultura. Um mundo agora civilizado. Como nos assinala Adorno (1995, p. 119) a partir da referência de Freud "de que a civilização, por seu turno, origina e fortalece progressivamente o que é anticivilizatório". $\mathrm{Ou}$ seja, a própria barbárie. A obra nos põe frente às contradições da própria civilização.

Podemos, então, indagar: O mundo assolado por barbáries pode ser ressignificado artisticamente como espaço de resistência?

\section{Considerações}

Os textos em questão são impactantes a princípio, pois põem o leitor diante de situações que provocam uma reflexão, nos convidando a sairmos da nossa zona de conforto e nos posicionarmos frente às suas evocações. É a literatura que ultrapassa os limites de não aceitar o mundo como ele é e se torna ponto de partida de sua reconstrução. São obras que mobilizam as nossas emoções, sentimentos, e não dá para sorrir. Como nos chama atenção Adorno (2001, p. 15-16) "Não dá para rir disso" quando se refere à arte que trata do sofrimento passado pelos judeus no holocausto, uma vez que ele afirma que "a arte, que não é mais possível se não for reflexiva, deve renunciar por si mesma à alegria". 
No percurso da leitura nos deparamos com as barbáries produzidas pela escravidão e pela colonização branca na Nigéria. Os dois textos publicados em períodos distintos, ou melhor, em séculos diferentes, se encontram na necessidade de mostrar ao leitor acontecimentos que não podem e nem devem ser esquecidos.

O texto literário como arte propõe ao leitor uma entrada despojada no mundo da ficção, mas ao mesmo tempo este leitor tem uma história e uma experiência que no encontro com o texto faz o necessário confronto, estabelecendo conflitos nos pontos de vista.

É importante ressaltar que Adorno nos alerta que o processo de emancipação dos sujeitos se dá pela resistência e pela autonomia. O texto literário pode se constituir nesse espaço, pois ao adentramos na linguagem ficcional que parte de uma dada realidade, nós, leitores, temos a oportunidade de conhecer lugares, pessoas, vidas, conflitos, costumes que fazem um contraponto com as nossas próprias vidas.

\section{Referências}

ADICHIE, Chimamanda Ngozi. Hibisco Roxo. Tradução de Júlia Romeu. São Paulo: Companhia das Letras, 2011.

ADORNO Theodor W. A arte é alegre? In: OLIVEIRA, Newton Ramos de; ZUIN, Antônio Alvares Soares; PUCCI, Bruno (Org.). Teoria Crítica, Estética e Educação. Campinas, SP: Autores Associados, Piracicaba, SP: Editora UNIMEP, 2001.

. Educação e Emancipação. São Paulo: Paz e Terra, 1995.

ASSIS, Machado de. Pai contra Mãe. In: . Contos Escolhidos. São Paulo: Martin Claret, 2012. 